\title{
Spawning season, recruitment and early life distribution of Anchoa tricolor (Spix and Agassiz, 1829) in a tropical bay in southeastern Brazil
}

\author{
Araújo, FG. *, Silva, MA. *, Azevedo, MCC. and Santos, JNS. \\ Laboratório de Ecologia de Peixes, Universidade Federal Rural do Rio de Janeiro - UFRRJ, \\ Antiga Rodovia Rio-São Paulo, Km 47, CEP 23851-970, Seropédica, RJ, Brazil \\ *e-mail: marciobio@ig.com.br, gerson@ufrrj.br \\ Received November 1, 2006 - Accepted June 15, 2007 - Distributed November 30, 2008
}

(With 7 figures)

\begin{abstract}
The pattern of the use of the Sepetiba Bay, a semi-closed $450 \mathrm{~km}^{2}$ area in southeastern Brazil, by Anchoa tricolor was investigated to assess spawning period, recruitment and to detect spatial-temporal patterns of this major fishery resource. Fishes were sampled by seine nets, from spring, 1998 to winter, 1999 and by beach seine, from spring, 1998 to winter, 2000. Reproductive season, measured in terms of GSI, gonad development and appearance of recruits, indicate that reproduction occurs from August to March, when they reach the best condition. Recruitment peaks in winter/ spring at sandy beaches where they stay until late summer, moving toward deeper bay areas during autumn. After that, they join adults and perform movements between the bay and the adjacent continental shelf to reproduce.
\end{abstract}

Keywords: reproduction, condition, anchovies, Engraulidae, recruitment.

\section{Período de reprodução, recrutamento e distribuição de jovens de Anchoa tricolor (Spix and Agassiz, 1829) em uma baía tropical do sudeste do Brasil}

\begin{abstract}
Resumo
O padrão de uso da Baía de Sepetiba, uma área semifechada no Sudeste do Brasil, por Anchoa tricolor foi estudado visando determinar o período reprodutivo, recrutamento e detectar padrões de distribuição espacial e temporal. As amostras foram realizadas por rede de cerco, entre a primavera de 1998 e o inverno de 1999, e por arrasto de praia, da primavera de 1998 ao inverno de 2000. O período reprodutivo, estimado com base no índice gonadossomático, desenvolvimento gonadal e aparecimento de recrutas, ocorre de agosto a março, quando é atingida a melhor condição dos adultos. O recrutamento ocorre principalmente no inverno/primavera nas praias arenosas onde eles permanecem até fins do verão, movendo-se para áreas mais fundas da baia durante o outono. Depois disto eles se juntam aos adultos e fazem movimentos entre a baia e a plataforma costeira adjacente para reproduzir.
\end{abstract}

Palavras-chave: reprodução, condição, manjubas, Engraulidae, recrutamento.

\section{Introduction}

Fishes of the Engraulidae family, known as anchovies, are widely distributed in tropical and sub-tropical waters (McGowan and Berry, 1983). Most anchovies species spawn in open coastal areas in the inner continental shelf, and the juveniles recruit in protected shallow areas, which offer food and shelter against predators (MacGregor and Houde, 1996). As adults, they move, on a diel and seasonal basis, between open coastal areas and bays, concentrating in large schools, when they become vulnerable to commercial fisheries (Coto et al., 1988).

In Sepetiba bay, a semi-closed $450 \mathrm{~km}^{2}$ area in southeast Brazil (22 ${ }^{\circ} 54^{\prime}-23^{\circ} 04^{\prime} \mathrm{S}$ and $\left.43^{\circ} 34^{\prime}-44^{\circ} 10^{\prime} \mathrm{W}\right)$, Anchoa tricolor (Spix and Agassiz, 1829) rank among the most abundant fishes either, as juveniles recruiting at sandy

beaches, or as adults occupying deeper areas in the bay (Silva et al, 2004; Silva and Araújo, 2003). Anthropogenic activities from the outskirts of Rio de Janeiro city produce a large variety of effluents that bring into the bay about $290,900 \mathrm{~m}^{3} /$ day, resulting in organic loads of approximately 70,000 kg BOD/day (Araújo et al., 2002). Recently, the enhancement of Sepetiba Port, resulted in dredging the access channel to $20 \mathrm{~m}$ depth thus increasing pollution.

Anchoa tricolor has supported important subsistence and commercial fisheries, as well as being a major prey item for several other fish species. In recent years their stocks have declined to the point that the fishery has been severely affected (Silva and Araujo, 2003). One of the most critical periods in the recruitment process of this species is 
the survival of recruits in deteriorated areas of Sepetiba. Aspects of the reproductive biology and recruitment of $A$. tricolor in the Sepetiba Bay are unknown. The fishery of A. tricolor occurs between late winter and summer, when adults come into the bay (Silva and Araújo, 2003). In temperate areas the closed related bay anchovy (Anchoa mitchilli (Valenciennes, 1848)) is a serial spawner and has a reproductive season during spring/summer when virtually all females spawn at night (Zastrow et al., 1991).

Evidence to date appears to indicate that anchovies form well-defined shoals in the lower half of the water column during the day for feeding purposes; at night, anchovy shoals spread out considerably (Tudela and Palomera, 1997). The fishing of A. tricolor within the Sepetiba Bay occurs during daylight when the fish are feeding. This is probably associated with the vertical migration of plankton, when shoals are more concentrated.

In this study we examined the strategy of use of the Sepetiba bay by A. tricolor. The spawning period was investigated and related to the juvenile recruitment at sandy beaches. Furthermore, early life stages were assessed to detect eventual spatial-temporal pattern. We examined spawning season and length frequency distribution of A. tricolor occupying two bay areas. Specifically, we addressed the following questions: What is the role of Sepetiba Bay for A. tricolor early life history? Do spatial differences in sandy beaches influence juveniles?

\section{Material and Methods}

\subsection{Study area}

Sepetiba Bay (Figure 1) is a sedimentary embayment, which originated by an extensive process of sand deposition that formed a barrier beach at its southern bound. It has a wide communication with the Atlantic Ocean on its western boundary. The bay shows a mean depth of $8.6 \mathrm{~m}$, a maximum depth of $30 \mathrm{~m}$, and its drainage area is c.a. 2,700 $\mathrm{km}^{2}$ (Araújo et al., 2002). Waters are predominantly polyhaline (salinity average $=30$ ). The annual rainfall is between 1,000 and $2,100 \mathrm{~mm}$

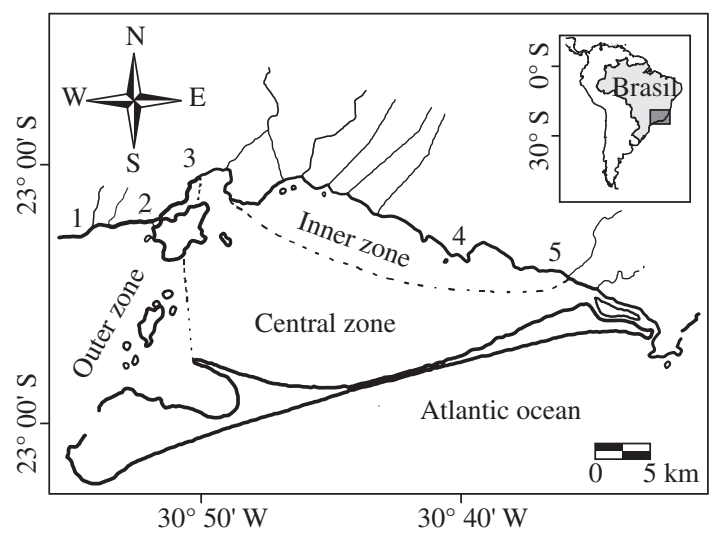

Figure 1. Sepetiba Bay, Southeastern Brazil, with indication of the sampling sites.
(Araújo et al., 2002) but this does not influence the Bay salinity due to the existence of small tributaries only. Most of the substrate is silt and mud. The tidal range is approximately $1 \mathrm{~m}$. Predominantly north-easterly and south-westerly winds activate thermal currents between the bay and the ocean.

Two bay zones were arbitrarily defined to maximize variation in habitat characteristics, including depth, salinity, transparency, temperature and influences of human activities. The outer zone has a sandy and gravel bottom and was close to the sea limit (highest salinity, transparency, depth and lowest temperature); the inner zone, with opposite oceanographic conditions, has a heavy mud bottom and was located within a protected area of the Bay, near to anthropogenic influences from urban-industrial wastes.

\subsection{Sampling}

Two fish sampling programmes were accomplished, one using beach seine nets ( $10 \mathrm{~m}$ long, $2 \mathrm{~m}$ deep beach seine with $7 \mathrm{~mm}$ mesh) to catch early juveniles, and other using seines to catch adults in the deeper areas of the Bay. Beach seine were performed monthly, from September 1998 to August 2000, at five sites, during the day. The net was pulled through the water parallel to the shore (1.5 depth) for a distance of $30 \mathrm{~m}$ and then onto the shore. Three replicates seines were performed at each site. Samples were carried out in site 1, 2 and 3 (outer zone) and sites 4 and 5 (inner zone).

Seine netting in deep areas adjacent to central bay islands (limit between outer and inner zones) was carried out using a $15 \mathrm{~m}$ long boat provide with acoustics echo sounder Royal RV400 equipment to monitor fishing procedure. Samplings were performed monthly from September 1998 to October August 1999. The net was $240 \mathrm{~m}$ long, $27 \mathrm{~m}$ deep with an $8 \mathrm{~mm}$ stretch mesh size in the middle-upper half and $10 \mathrm{~mm}$ stretch mesh size in the middle-lower half. The net was released with the help of a small auxiliary boat, while the main fishing boat encircled the schooling, closing the net. Total catches (by numbers and weight) and the length-frequency distribution were recorded for each tow. Sub-samples from very abundant catches were made.

\subsection{Reproduction}

From the fixative-preserved ovaries, histological sections were prepared. Tissue was sectioned at 5-6 $\mu \mathrm{m}$ and stained with haemotoxylin and eosin. Each slide was examined at x100 magnification and classified according to the most advanced stage of oocyte development, the level of atresia and the presence or absence of postovulatory follicles.

The oocytes were classified as 1) unyolked; 2) partially yolked; 3 ) advanced yolked; and 4) with migratory nucleus or hydrated. The relative abundance of $\alpha$-atretic to advanced yolked oocytes was also noted. Each ovary was examined histologically and classified (Table 1). Stages maturation as well as juveniles and adults were 
Table 1. Microscopy description of gonad maturation stages for females A. tricolor in the Sepetiba Bay, Brazil.

\begin{tabular}{ll}
\hline \multicolumn{1}{c}{ Stages } & \multicolumn{1}{c}{ Characteristics } \\
\hline 1 - Immature/recovering & Only oocytes 1 and 2. \\
2 - Mature & $\begin{array}{l}\text { Mostly oocytes 2 and 3. } \\
\text { Oocytes 1, 2, 3 and 4, } \\
\text { 3 - Ripe }\end{array}$ \\
& $\begin{array}{l}\text { with the latter being more } \\
\text { numerous. }\end{array}$ \\
4a - Partially spent & $\begin{array}{l}\text { Oocytes 1, 2, 3 and 4, } \\
\text { empty follicles. }\end{array}$ \\
4b - Totally spent & $\begin{array}{l}\text { Numerous oocytes 1 and 2, } \\
\text { empty follicles }\end{array}$ \\
\hline
\end{tabular}

separated according to the macroscopy scale proposed by Vazzoler (1996) and confirmed by histological observations.

The Fulton condition index $\left(\mathrm{BW} \times \mathrm{BL}^{-3}\right)$, where $\mathrm{BW}=$ body weight and $\mathrm{BL}=$ body length, was calculated on a monthly basis. The gonadosomatic index was calculated as $\left(\mathrm{GW} \times \mathrm{BW}^{-1}\right) \times 100$, where $\mathrm{BW}=$ wet body wt. $(\mathrm{g})$ and $\mathrm{GW}=$ wet gonad wt. $(\mathrm{g})$.

\section{Results}

\subsection{Size structure}

\subsubsection{Beach seines}

Size of individuals ranged from 18 to $112 \mathrm{~mm}$ Total Length (TL), with highest numbers between 22 and $56 \mathrm{~mm}$ TL (Figure 2).

Monthly length-frequencies indicate that a wide recruitment period for A. tricolor occur in the Sepetiba Bay. In the outer Bay zone, young-of-the-year appeared in spring 1998 (18-30 mm TL) reaching in summer 1998/1999 a size 36-46 mm TL; during autumn 1999 they were not recorded in the samples. Another cohort (18-40 mm TL) appeared in winter 1999 (mode $=26 \mathrm{~mm}$ TL), reaching 28-50 mm TL in summer 1999/2000, and again disappearing from the beach samplings in autumn 2000.

In the inner Bay zone, young-of-the-year appear in spring 1998 (18-28 mm TL), reaching 24-30 mm in summer 1998/99. They were not recorded during autumn, reappearing in large numbers in winter 1999, showing size ranging 50-62 $\mathrm{mm}$ TL.

Juveniles from spring 1998 showed a comparatively smaller size than juveniles from spring 1999, suggesting an earlier reproductive season in the second yearly period. Overall, individuals recorded in summer showed highest size when compared with other seasons.

\subsubsection{Seine}

Size of the captured individuals ranged from 76 to $120 \mathrm{~mm}$ TL, peaking at 100 and $116 \mathrm{~mm}$. The smallest individuals were common during winter with modes of approximately $84 \mathrm{~mm}$ TL (Figure 3). Higher abundance occurred in spring/summer when compared to autumn/winter.

\subsection{Reproductive season}

Of 330 ovaries examined, the majority showed advanced maturation stage, being common from August to March; ovaries showing immature/recovering stages were frequent from April to July (Figure 4). In September about $40 \%$ of the females showed early spawning stage.

Average GSI values increased from August to February peaking at September. Lower values were recorded from April to June (Figure 5). Fulton fish condition showed highest values from September to February and lowest in June (Figure 6).

\section{Discussion}

Anchoa tricolor probably spawns in the adjacent coastal area to the Sepetiba bay, since it has been reported to distribute in most saline bay areas, moving between the outer zone and the coastal shelf (Silva and Araújo, 2003). Most members of the Engraulidade family are reported to spawn in coastal zones and their eggs and larval phases enter estuaries and bays where they find protection and food availability (Coto et al., 1988; Macgregor and Houde, 1996). This could be a strategy for A. tricolor to optimise recruitment at a sandy beach in the Bay, by getting close to recruitment areas minimizing high mortality rates in this critical period as eggs, larvae and young-of-the-year. Predominant ocean currents that penetrate the Sepetiba Bay on the west side could transport eggs and larvae contributing to the high recruitment rate at the sandy beach in the outer Bay zone. Waters parcels entering Sepetiba Bay were reported by Stevenson et al. (1998). Since the early eighties the importance of sandy beaches in Sepetiba bay was reported by Pessanha et al. (2000), that ranked Engraulidae among the most abundant group of fish at beach seines, especially those located at the outer Bay, where conditions are close to the adjacent sea, and anthropogenic influences are comparatively low. Ten years later, Araújo et al. (1997) recorded this family as the second most abundant group of fishes at the same beaches, confirming the important role of these beaches.

Shoals formations are mechanisms for individual protection against predation. Some shoals performed vertical migration, moving to deeper areas during daylight hours, and dispersing at night, following plankton upward vertical migration (Lowe-Mcconnell, 1988). As a consequence, fishing occurs during the day, since at night there is not enough fish concentration to justify commercial investment, due to their spread out distribution. In Sepetiba Bay this pattern is found since fishing occurs only during daylight hours and takes place in deeper areas near island formations (Silva and Araújo, 2003).

Anchoa tricolor is a serial spawner with reproductive season from August to March, and this coincides with the increasing photoperiod in Sepetiba watershed area. 

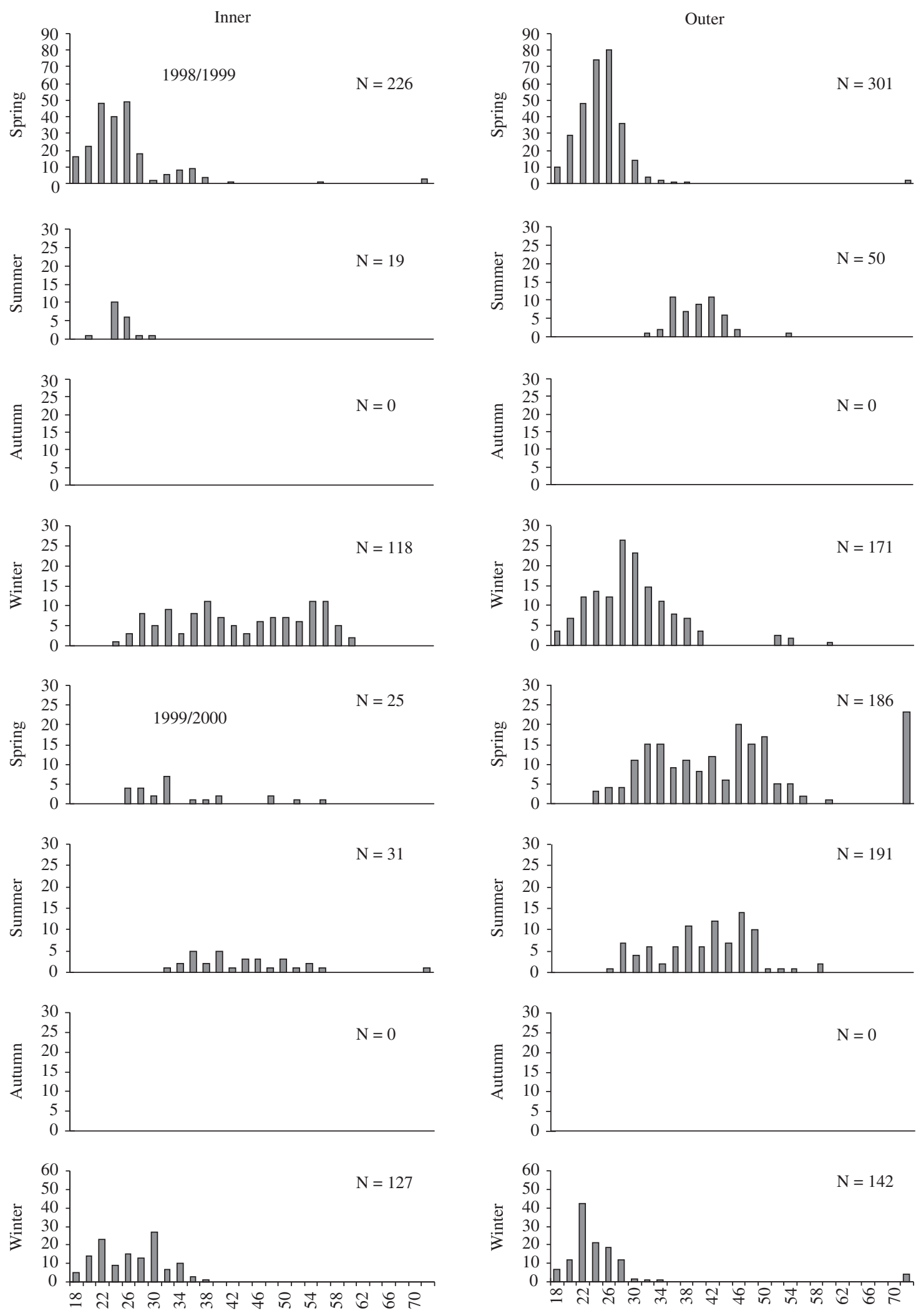

Total length (mm)

Figure 2. Length frequency distribution (in cm) for juveniles A. tricolor caught by beach seine, 1998/2000. 

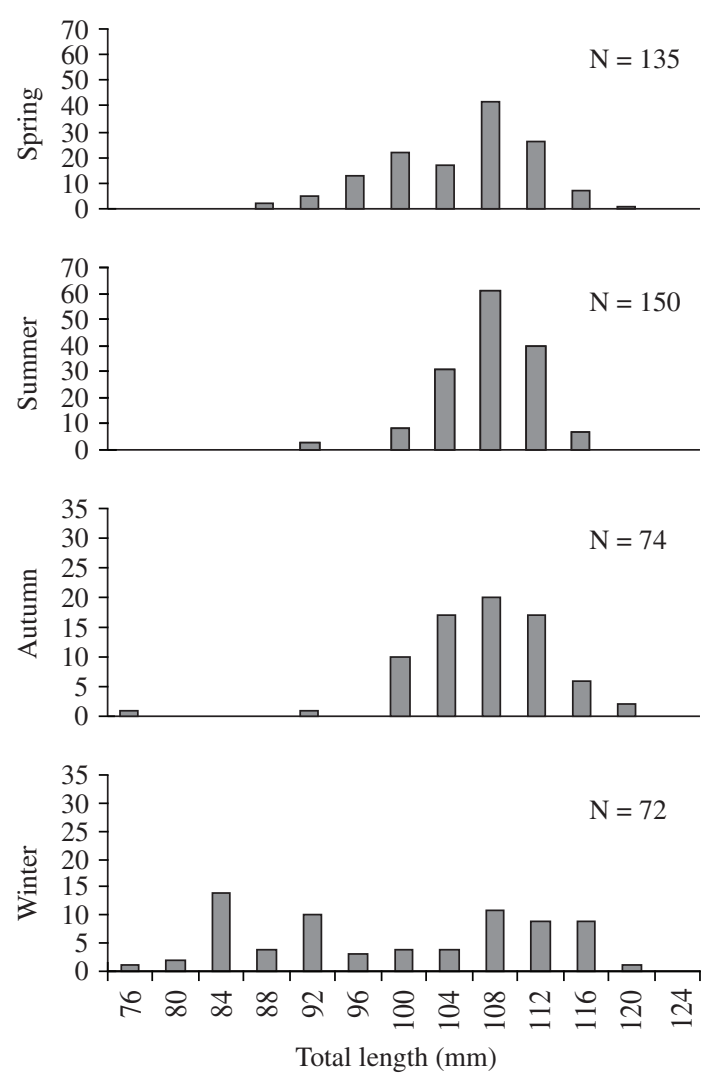

Figure 3. Length frequency distribution (in $\mathrm{cm}$ ) for adult A. tricolor caught by seine, 1998/1999.

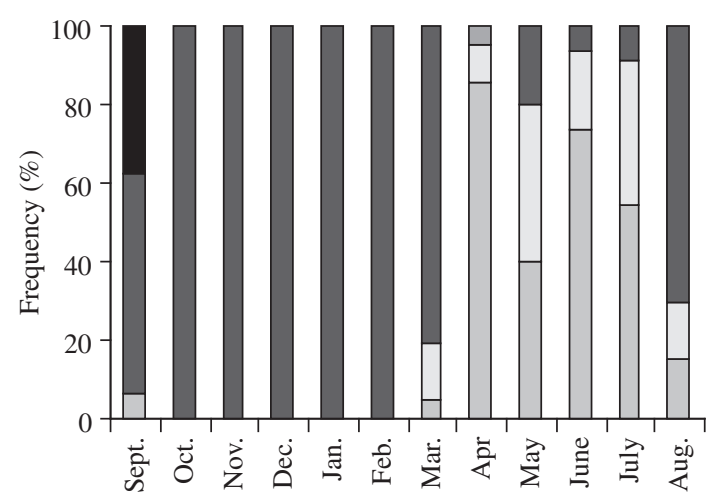

\section{$\square 1 \quad \square 2 \quad \square 3 \quad \square 4 \mathrm{a} \quad \square 4 \mathrm{~b}$}

Figure 4. Monthly relative frequency (\%) of gonad stages for females A. tricolor in the Sepetiba Bay, 1998/1999.

The occurrence of ripe individuals between October and February that contain eggs in different development stages (Oocytes 1, 2, 3 and 4, with the latter being more numerous) is an indication that serial spawn occurs. Raising temperature in this period probably increases zooplankton availability favoring larvae development. It was found that organic and inorganic nutrient loads

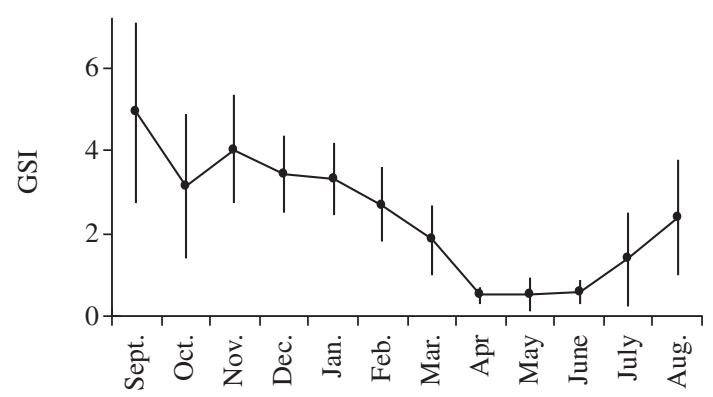

Figure 5. Means gonadosomatic index and standard errors (vertical bars) for A. tricolor in the Sepetiba Bay, 1998/1999.

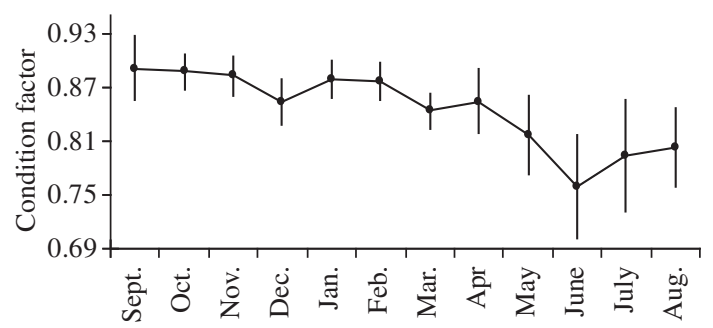

Figure 6. Mean condition factor and standard errors (vertical bars) for A. tricolor in the Sepetiba Bay, 1998/1999.

brought into the bays by tributaries and drainage channels, favour larvae and juvenile development (Macgregor and Houde, 1996). Castrow and Cowen (1991) found a correlation between A. mitchilli and copepod nauplius concentrations, and related the survival of anchovies to nauplius concentration. Another explanation is that the adults spawn in direct response to temperature and photoperiod, as suggested by Zastrow et al. (1991), and that the association between older larvae and their prey occurs as the result of spatio-temporal variability in survival of first-feeding larvae.

The relatively high gonadosomatic index (GSI) found between August and March suggests a wide spawning period between late winter and late summer, and a recovering period between April and June. Unexpectedly, only few early recruits ( $\mathrm{TL}<30 \mathrm{~mm}$ ) were recorded in summer which seems to be the final stage of the reproductive period; such early recruits are common in winter/spring. Spawns probably begin in winter in spite of relatively low GSI, which is influenced by large numbers of individuals with 76-92 $\mathrm{mm}$ TL that join adults in deeper bay areas. Furthermore, no information is available on temporal occurrence of eggs and larvae and how long they take to reach the recruitment size. Fish condition was at the highest between September and February overlapping with GSI peaks. Condition, according to Vazzoler and Vazzoler (1965) enables the assessment of variation in the overall health of the species, dictated by several factors, among them, feeding availability. The highest condition recorded between September and February suggests that better feeding conditions in this period 
allowed reserve tissue concentration and consequently the best physiological condition. The best condition for A. tricolor during the spawning season coincides with the hypothesis that this species spawns in a period of high food availability. In spite of Vazzoler and Vazzoler (1965) considering the spawning period as a time of high energetic loss, and consequent low condition, this was not observed for A. tricolor in the Sepetiba Bay. Hunter and Leong (1981) indicate that most of the energy required for spawning has to be obtained from the food consumed during the spawning period itself.

Growth of clupeoids in tropical waters is faster and the life cycle is shorter when compared to temperate areas. Engraulis ringens Jenyns, 1842, a very common species off the Peruvian coast, survives up to eighteen months and this lifetime period is remarkably shorter when compared to the Engraulis mordax Girard, 1854 population off the California coast that reaches up to 5 or 6 years (LoweMcconnell, 1988). In Sepetiba Bay, A. tricolor spent almost one year at the sandy beaches, moving toward deeper areas during autumn. After that they reach a size of 76-92 mm TL and join adults in deeper Bay areas when they are supposed to move between the outer bay and the continental shelf to reproduce. A part of small sized individuals (50-62 $\mathrm{mm}$ TL) return from the deep bay areas to the beaches in winter joining the recruits (Figure 7).

Individuals recruited in spring with $18-30 \mathrm{~mm}$ TL reach 36-46 $\mathrm{mm}$ TL in summer in the outer Bay, and only $24-30 \mathrm{~mm}$ TL in the inner Bay. The small sample size in summer 1998/1999 in the inner zone is insufficient to support a robust inference on growth. Betweenyear changes in recruitment and growth rate could also occur. In 1998/99 reproduction could have occurred later than in $1999 / 00$, as indicated by the different size of early recruits in spring. In autumn no recruits were recorded at beaches suggesting a movement away from this area in this period. Another hypothesis is that high mortality in this period could occur and explain the absence of fish in this season.

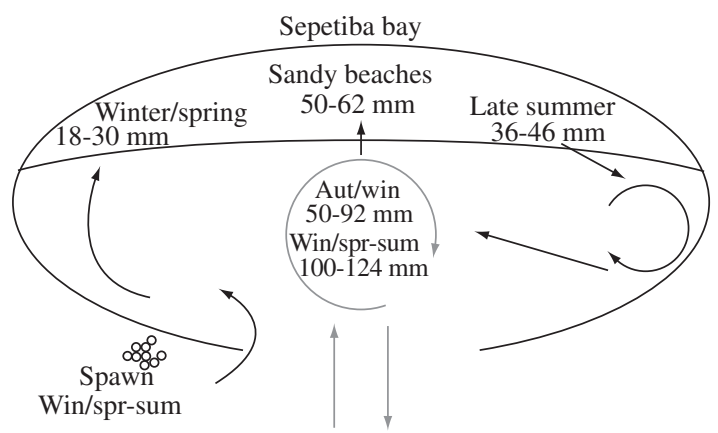

Continental shelf

Figure 7. Hypothetical diagram for life cycle of A. tricolor in the Sepetiba Bay. Black arrows correspond to recruits and juveniles; Gray arrows correspond to adults.
Overall a hypothesis for A. tricolor early life cycle can be drawn from the above results (Figure 7). Adults penetrate into the Bay in winter, spawning near to the bay connection with the sea, and young-of-the-year are brought to outer bay sandy beaches by incoming currents favoring recruitment. Young-of-the-year spend almost the first year at sandy beaches, then move away to deeper areas in the Bay, which are used as rearing grounds. After two years old ( $>110 \mathrm{~mm}$ TL) they join adults migrating to the continental shelf.

Acknowledgements - We thank André Luiz Machado Pessanha and Antônio Gomes Cruz-Filho for help with field work; and to technical staff of the Laboratory of Fish Ecology, University Federal Rural of Rio de Janeiro for useful help in the laboratory. Dr. Labbish Ning Chao and an anonymous referee provided comments that led to substantial improvement to earlier drafts of the manuscript. This research is part of a Dissertation submitted to the Animal Biology Post-Graduate Course, in partial fulfillment of the requirements for the M. Sc. degree.

\section{References}

ARAÚJO, FG., CRUZ-FILHO, AG., AZEVEDO, MCC., SANTOS, ACA. and FERNANDES, LAM., 1997. Estrutura da comunidade de peixes jovens da margem continental da Baía de Sepetiba, RJ. Acta Biol. Leopold., vol. 19, no. 1, p. 61-83.

ARAÚJO, FG., AZEVEDO, MCC., SILVA, MA., PESSANHA, ALM., GOMES, ID., and CRUZ-FILHO, AG., 2002. Environmental influences on the demersal fish assemblages in Sepetiba Bay, Brazil. Estuaries, vol. 25, no. 3, p. 441-450.

CASTROW, L. and COWEN, RK., 1991. Environmental factors affecting the early life history of bay anchovy Anchoa mitchilli in Great South Bay, New York. Mar. Ecol. Prog. Ser., vol. 76, p. $235-247$

COTO, CF., LUNA, AO., CALVO, AL. and GARCÍA, FZ., 1988. Abundancia de algunas especies de Anchoas en la laguna de Términos (México), estimada a través de la captura de huevos. An. Inst. Cienc. Mar Limnol. Univ. Nac. Auton. Mex., vol. 15 , no. 1 , p. $125-134$.

HUNTER, JR. and LEONG, R., 1981. The spawning energetics of female Northern anchovy. Engraulis mordax. Fish. Bull., vol. 79 , no. 2 , p. $215-230$

LOWE-MCCONNELL, RH., 1988. Ecological studies in tropical fish communities. Cambridge: University Press. 382 p.

MACGREGOR, JM. and HOUDE, ED., 1996. OnshoreOffshore pattern and variability in distribution and abundance of bay anchovy Anchoa mitchilli eggs and larvae in Cheasapeake Bay. Mar. Ecol. Prog. Ser., vol. 138, p. 15-25.

MCGOWAN, MF. and BERRY, FH., 1983. Clupeiformes: Development and Relationships. In Ontogeny and Systematics of Fishes - Am. Soc. Ichthyol. Herpetol. Spec. Publ. 1, Allen Press, Lawrence, KS, pp. 108-126.

PESSANHA, ALM., ARAÚJO, FG., AZEVEDO, MCC. and GOMES, ID., 2000. Variações temporais e espaciais na composição e estrutura da comunidade de peixes jovens da Baia de Sepetiba, Rio de Janeiro. Rev. Bras. Zool., vol. 17, no. 1, p. $251-261$

SILVA, MA., ARAÚJO, FG., AZEVEDO, MCC. and SANTOS, JNS., 2004. The nursery function of sandy beaches in Brazilian 
tropical bay for 0-group anchovies (Teleostei: Engraulidade): diel, seasonal and spatial patterns. J. Mar. Biol. Ass. U. K., vol. 84 , no. 6 , p. 1229-1232.

SILVA, MA. and ARAÚJO, FG., 2003. Influência dos fatores ambientais na fauna acompanhante na pesca da manjuba Anchoa tricolor (Osteichthyes-Engraulidae) na Baía de Sepetiba, Rio de Janeiro. Rev. Bras. Zool., vol. 20, no. 3, p. 367-371.

STEVENSON, MR., DIAS-BRITO, D., STECH, JL. and KAMPEL, M., 1998. How do cold water biota arrive in a tropical bay near Rio de Janeiro, Brasil? Cont. Shelf Res., vol. 18, no.13, p. $1595-1612$.

TUDELA, S. and PALOMERA, I., 1997. Trophic ecology of the European anchovy Engraulis encrasilocus in the Catalan sea (northwest mediterranean). Mar. Ecol. Prog. Ser., vol. 160, p. $121-134$

VAZZOLER, AEAM., 1996. Biologia da reprodução de peixes Teleósteos: Teoria e Prática. São Paulo: Ed. EDUEM. SBI $\mathrm{CNPq} /$ Nupelia (UEM).

VAZZOLER, AEAM. and VAZZOLER, G., 1965. Relation between condition factor and sexual development in Sardinella aurita (Cuv and Val 1847). An. Acad. Bras. Cienc., vol. 37, suppl., p. 353-359.

ZASTROW, CE., HOUDE, ED. and MORIN, LG., 1991. Spawning, fecundity, hatch-date frequency and young-of-theyear growth of bay anchovy Anchoa mitchilli in mid-Chesapeake bay. Mar. Ecol. Prog. Ser, vol. 73, p. 161-171. 